\title{
Correspondence
}

\section{Laureate of the History of Anesthesia program}

To the Editor:

In 1995 the American Society of Anesthesiologists' (ASA) Wood Library-Museum (WLM) established an international program to recognize the importance of the history of anesthesia by awarding, every four years, the title of Laureate of the History of Anesthesia to an individual who has made outstanding contributions to the study of the development of anesthesia through the years.

In 1996 Dr. Gwen Wilson of Sydney, Australia was named the first Laureate of the History of Anesthesia. The WLM is presently inviting nominations for the year 2000 Laureate, to be announced in October, 1999 and awarded during the annual meeting of the ASA in October, 2000. (The award ceremony includes presentation of a $\$ 3,000$ honorarium, a medal and an appropriate diploma. The awardee will also be reimbursed for round-trip tourist class airfare between his/her home and San Francisco, as well as a $\$ 175$ per diem for three days in San Francisco.)

Any individual who wishes to submit a nomination must provide an English language copy of the nominee's curriculum vitae and complete bibliography. The nominator is also to submit a letter to support the nomination by providing a detailed assessment of the unique value and merits of the nominee's contribution to the study of the history of anesthesia. This letter of nomination will be a significant factor in the selection of the Laureate. Letters of support of the nomination, are also invited. The nominating letter must also be accompanied by a statement signed by the nominee that he/she agrees to permit his/her name to be proposed. A representative sample of the nominee's historical writing in English language shall accompany the nomination letter. Nominations made for the 1996 Laureate award can be renewed and will be considered for the year 2000 award by sending to the WLM an update of the candidate's curriculum vitae and bibliography together with updated letters of support.

All nomination materials must be received by July 31,1999 at the Wood-Library Museum at $520 \mathrm{~N}$. Northwest Highway, Park Ridge, IL 60068-2573, the address to which requests for further information should be sent by mail only, please.
Nicholas M. Greene MD

Illinois, USA

\section{What does it take}

To the Editor:

I have had the privilege to work in the Department of Anesthesia at McGill for fifteen years. One of the most impressive occasions with which I was involved took place on March 15, 1991 - the launching of the Harold Griffith commemorative stamp by Canada Post.

Dr. Griffith died in May 1985 and left behind a rich heritage including his study demonstrating the safety and efficacy of curare during surgery which changed the practice of anesthesia world-wide. Dr. Griffith inaugurated a training programme for anesthesiologists in World War II which was to be the predecessor of the McGill Diploma Course in Anesthesia, played a leading role in the organization of anesthesia in Canada and around the world, was the first President of the Canadian Anaesthesiologists' Society, Chairman of the Board of Trustees of the International Anesthesia Research Society and President of the World Federation of Anesthesiologists at its first meeting in Holland in 1959.

Since 1996, we have nominated Dr. Harold Griffith to be inducted into the Canadian Medical Hall of Fame. This institution was established in 1993 to celebrate discovery and innovation in medical science and to pay tribute to Canadian men and women who have contributed to the understanding of disease and advancement of health of people everywhere. Previous inductees have included Drs. Maude Abbott, Charles-Best, William Osler, Robert Salter, William Mustand and Sir Frederick Grant Banting.

We need your help to increase the awareness of the committee members who will decide next fall whether Dr. Griffith deserves a place in the Canadian Medical Hall of Fame. Your letters of support should be directed to Ms. Betsy Little, Executive Director, The Canadian Medical Hall of Fame, P.O. Box 5015, 100 Perth Drive, London, ON N6A 5K8.

As Dr. J. Earl Wynands points out in his letter of nonimation, "A physician who made the single greatest contribution to a specialty since its inception, has been given his country's highest award and is interna- 